\title{
Synopsis of the knowledge on the Brazilian aplacophorans (Mollusca: Caudofoveata \& Solenogastres)
}

\author{
Flávio Dias Passos $^{1,2 * \mathbb{D}, \text { Marcel Sabino Miranda }}{ }^{2}$ \& Paulo Vinicius Ferraz Corrêa ${ }^{2} \mathbb{C}$ \\ ${ }^{1}$ Universidade Estadual de Campinas, Departamento de Biologia Animal, Instituto de Biologia, \\ Cx. Postal 6109, CEP 13083-970, Campinas, SP, Brasil \\ ${ }^{2}$ Universidade Estadual de Campinas, Programa de Pós-Graduação em Biologia Animal, CEP 13083-970, \\ Campinas, SP, Brasil \\ *Corresponding author: Flávio Dias Passos, e-mail: flaviodp@unicamp.br
}

PASSOS, F.D., MIRANDA, M. S., CORREAA, P. V. F. Synopsis of the knowledge on the Brazilian aplacophorans (Mollusca: Caudofoveata \& Solenogastres). Biota Neotropica. 19(1): e20180545. http://dx.doi.org/ 10.1590/16760611-BN-2018-0545

\begin{abstract}
Aplacophorans are well known as exclusively marine benthic molluscs with a vermiform body covered by aragonitic sclerites (also called spicules), whose species are widely distributed from the sublittoral down to the abyss. Currently, only nine species are known from Brazil (one Solenogastres and eight Caudofoveata), but these very few records are no longer a reflection of an existing low diversity. Sampling in deep waters has been conducted recently in oil-rich areas of the Brazilian coast, and the museum collections have now many aplacophoran lots. There is a need to learn about and/or install some microscopical facilities in Brazilian institutions, to form expertise for the investigations on these generally small animals. With studies on taxonomy, phylogeny, biogeography and ecology, important questions will be surely answered about the diversity, distribution, and the relationship among the deep-sea fauna from Brazil and from other places.
\end{abstract}

Keywords: Aplacophora, molluscs, biodiversity, Southwestern Atlantic.

\section{Sinopse do conhecimento sobre os aplacóforos brasileiros (Mollusca: Caudofoveata \& Solenogastres)}

Resumo: Os aplacóforos são bem conhecidos como moluscos bentônicos exclusivamente marinhos, que possuem um corpo vermiforme coberto por escleritos de aragonita (também chamados de espículas), e cujas espécies são amplamente distribuídas desde o sublittoral a até profundidades abissais. Atualmente, apenas nove espécies são conhecidas para o Brasil (uma de Solenogastres e oito de Caudofoveata), mas esses poucos registros não são um reflexo de uma baixa diversidade existente no nosso litoral. Recentemente, amostragens em águas profundas têm sido feitas em áreas da costa brasileira ricas em petróleo, e as coleções de museus possuem agora muitos lotes de aplacóforos. Há uma necessidade de aprender sobre e/ou instalar algumas condições de infraestrutura nas instituições brasileiras, com o intuito de formar competência para as investigações sobre estes animais geralmente pequenos. Com estudos sobre taxonomia, filogenia, biogeografia e ecologia, questões importantes serão certamente respondidas sobre a diversidade, distribuição e relação entre as faunas de grande profundidades do Brasil e de outros locais do mundo.

Palavras-chave: Aplacophora, molluscos, biodiversidade, Atlântico sul-ocidental. 


\section{Introduction}

Mollusca is a very diverse group of animals, with about 80,000 described living species (Bouchet et al. 2016). They are well known for the beautiful shells that many of its representatives bear (although not all have shells), and also for their ecological and economic importance. In this group there are very popular forms such as land and marine snails and slugs, oysters, mussels, squids and octopuses. They are animals found in almost all types of environments, like the sea bottom or the seawater column, in freshwater and in land ecosystems. This huge biodiversity is grouped into a single phylum, whose monophyly is practically unanimous, based on both morphological (e.g., Salvini-Plawen 1980, Haszprunar 2000) and molecular evidences (e.g., Passamaneck et al. 2004, Kocot et al. 2011, Smith et al. 2011). Most malacologists agree that there are eight living lineages: Solenogastres, Caudofoveata, Polyplacophora, Bivalvia, Monoplacophora, Scaphopoda, Gastropoda and Cephalopoda (Kocot 2013, Giribet 2014, Schrödl \& Stöger 2014).

Aplacophora is very distinct from the other molluscs, with characteristics that for a long time have been considered similar to the ones that may have existed in the common molluscan ancestor. Their vermiform body is covered by aragonitic sclerites (also sometimes called spicules) instead of a shell, and the pallial cavity is positioned at the posterior end of the body. Because of these presumably plesiomorphic characters, Aplacophora has been traditionally placed as a sister group of other molluscs (e.g., Salvini-Plawen \& Steiner 1996). An alternative hypothesis groups them with Polyplacophora in a clade called Aculifera, which has been recently supported by molecular and phylogenomic data (e. g., Kocot et al. 2011, Smith et al. 2011, Vinther et al. 2012); Aculifera is, in turn, the sister group to Conchifera, which is composed by the remaining molluscs.

Two groups are recognized as aplacophorans, Caudofoveata Boettger, 1956 (or Chaetodermomorpha Pelseneer, 1906) and Solenogastres Gegenbaur, 1878 (or Neomeniomorpha Pelseneer, 1906), distinguished by external and internal characteristics. Both have living species in all oceans, with most of them being distributed between 200 and 3,000 meters depth, although one (Chevroderma hadalis Ivanov 1996) was recorded up to about 8,400 meters (Ivanov 1996). They are, in general, small animals, less than five millimeters long, with some few species reaching up to $40 \mathrm{~cm}$ (Ivanov \& Scheltema 2007). Like other molluscs, a radula is present and the anus is positioned in the mantle cavity, as well as the genital openings and the gills. There is a tetraneural nervous system but a distinct head is lacking, as well as kidneys, or nephridia.

Solenogastres comprises about 280 species (Todt 2013, GarcíaÁlvarez et al. 2014), characteristically bearing a ciliated sliding ventral furrow, used for locomotion on both soft bottoms and hard substrates. Within this furrow there is a ciliated epithelium considered homologous to the foot of other molluscs (Scheltema 1978). They form a very diverse aplacophoran group, whose species diversity is currently classified in four orders and 23 families (García-Álvarez \& Salvini-Plawen 2007, García-Álvarez et al. 2014). Most of them feed on cnidarians. They are hermaphrodites and the digestive gland is simple and undivided (Scheltema et al. 1994, García-Álvarez et al. 2014). Respiratory organs are either absent or developed as respiratory folds in the mantle cavity.

Caudofoveata is less diverse, composed of about 130 species (Todt 2013, Salvini-Plawen \& García-Álvarez 2014), which are classified into only three families: Chaetodermatidae Theel, 1875, Limifossoridae
Salvini-Plawen, 1970 and Prochaetodermatidae Salvini-Plawen, 1972 [although two other families were proposed by Ivanov (1981), but not generally accepted (MolluscaBase 2018)]. They are all infaunal and feed on detritus and occasionally on foraminiferans. Their mouth is surrounded as a whole or in part by an oral shield (or oral disc, or pedal shield) that is absent in Solenogastres. The oral shield does not bear sclerites on it but have one or more rows of distinct sclerites surrounding it. It is used in locomotion, and also has a sensory function (Salvini-Plawen \& García-Alvarez 2014). In the posterior end of the body, the pallial cavity contains a pair of bipectinate ctenidia, considered homologous with those of other molluscs. They are also distinguished from Solenogastres by the absence of the ventral foot groove, by their dioecious condition and internally by the presence of a well-developed divided digestive tract and a simpler reproductive tract (Scheltema et al. 1994).

In comparison to other molluscs, Aplacophora is poorly known, because, in large part, they occur in deeper waters and are thus less accessible, as discussed by Todt (2013). Moreover, these animals have, in general, small dimensions and studying them requires the observation of important microscopic features, such as the structure of the sclerites, radula and internal organs. For Caudofoveata, the radula and sclerite characters are somewhat sufficient to identify its species, whereas for Solenogastres these and histological characters of the foregut glands are enough for family level, with additional characters of the gonopericardial system being necessary for species assignment. Overall, in addition to Aplacophora being less accessible, their taxonomy requires time-consuming observations and is extremely hard for intrained taxonomists. Thus, among all molluscan groups, the diversity of Aplacophora is one of the least known, related to the small number of specialists involved in their taxonomy. At this moment, there are only few groups of researchers distributed in the United States of America, Spain, Norway, Russia, Japan, Colombia, Germany, Austria, and now in Brazil. It is noteworthy that three of them have recently passed away - Christopher Schander (Norway), Luidfried Salvini-Plawen (Austria) and Amélie Scheltema (USA) - leaving the Aplacophora orphaned of its most important authorities.

In the Atlantic Ocean, Aplacophorans is best known from the north hemisphere, from where there are more abundant records, especially in Europe and USA, including the Gulf of Mexico (e.g., Salvini-Plawen 1967, 1968, 1972, 1996, Scheltema 1985, Scheltema \& Ivanov 2000, Schander et al. 2006, Ivanov et al. 2009, Ivanov \& Scheltema 2008, 2009, Señaris et al. 2014). There are also species known from the Caribbean, Colômbia and Suriname (e.g., Salvini-Plawen 1972, 1992, Ivanov \& Scheltema 2008, Gracia et al. 2013), but further south in the Atlantic American coast records of aplacophoran species are much more scattered. For Brazil, Uruguay and Argentina they are very poorly known, despite the large and diverse coast these countries bear. Three species of Caudofovetata and one of Solenogastres are known from Uruguay (Scheltema 1985, Salvini-Plawen 1992, Scheltema \& Ivanov 2000, Scarabino 2003); and for Argentina, six and ten species, respectively (Scheltema \& Ivanov 2000, Forcelli 2000, García-Álvarez $\&$ Salvini-Plawen 2007). For the Brazilian littoral, the occurrence of aplacophorans is presumably very restricted, based on existing published records. These records are gathered here, additionally pointing out some problems that have hampered the studies of these molluses in our country. 


\section{Material and Methods}

All literature related to Aplacophora was reviewed, aiming to find information about the species already recorded from Brazil. Apart from this, the molluscan scientific collections of the Museum of Zoology of the State University of Campinas "Prof. Adão José Cardoso" (ZUEC), of the National Museum of Rio de Janeiro (MNRJ), and of the Museum of Zoology of the University of São Paulo (MZUSP) were consulted. Then, pictures of the aplacophoran species already recorded were taken.

\section{Results}

The first record of an aplacophoran from Brazil was made by Rios (1980), based on two specimens of Neomenia herwigi Kaiser, 1976 (Neomeniidae) collected in the Rio Grande do Sul State (Figure 1). This species was also listed in the subsequent catalogs of Rios (1985, 1994, 2009), and up to now is the single Solenogastres known from our littoral. It is well known as a giant aplacophoran species, for its individuals can reach up to 20 centimeters in length (Rios 1980). It was originally described from Argentinian waters (Kaiser 1976). Apart from this species, there is also only one reference of other Brazilian Solenogastres, "Proneomenia (?) sp." (Proneomeniidae), by Simone (2004), collected by the Revizee Project - Score South.

For Caudofoveata, there are more records, but most of them are not very precise, as there are no data about the sampling locality. Rios (1994, 2009), for example, listed two species of Limifossoridae and one of Chaetodermatidae, but all of these were not described in detail, nor are there bibliographic references or biological material on which they were based. In addition to these records, other two can be mentioned: Cruz et al. (1998), who studied the radula of an undescribed species of Falcidens Salvini-Plawen, 1968 collected from off the coast of Rio de Janeiro; and Martins (2008), who made great taxonomic discoveries - four species new to science - based on specimens collected in the southeastern and southern coast, but these are not formally published yet. Aside from these incomplete records, there are only eight Caudofoveata species known from Brazilian waters: Chevroderma turnerae Scheltema, 1985 and Spathoderma bulbosum Ivanov \& Scheltema, 2008 (Prochaetodermatidae), originally described by examination of specimens also collected in deep waters from the northeastern coast (Scheltema 1985, Ivanov \& Scheltema 2008); and F. targatus Salvini-Plawen, 1992, F. acutargatus Salvini-Plawen, 1992, F. australocaudatus Passos, Corrêa \& Todt, 2017 (Chaetodermatidae), Claviderma amplum Ivanov \& Scheltema, 2008, C. crassum Ivanov \& Scheltema, 2008, and C. virium Corrêa, Miranda \& Passos, 2018 (Prochaetodermatidae), recently discovered from the Campos Basin, off the Espírito Santo and Rio de Janeiro States (Corrêa et al. 2014, 2018, Passos et al. 2017). Chevroderma turnerae is widely distributed, known as a lower continental rise and abyssal species occurring in the Atlantic and Indian Oceans (Scheltema 1985, Scheltema \& Ivanov 2000, Ivanov \& Scheltema, 2008). S. bulbosum is until now restricted to the continental slope and rise in the eastern Atlantic (Ivanov \& Scheltema 2008). The record of F. acutargatus from the Campos Basin (Corrêa et al. 2014) represents the extension of occurrence of this species further to the south in the Americas; it was known only from North Carolina to the Caribbean (it remains, however, to be found in other countries from the northern part of South America and in the Brazilian north-eastern coast). F. targatus was originally described from the continental shelf of Uruguay (Salvini-Plawen 1992), and before this it was recorded by Scheltema (1990) as an undescribed species from Brazil. Corrêa et al. (2014) suggested that the distribution of this species must be more restricted, maybe for the influence of the delta rivers occurring in the north-eastern and northern Brazil. F. australocaudatus was recorded as a very abundant species from the shelf and slope of Campos Basin (Passos et al. 2017); it was compared with F. caudatus (Heath, 1918), a species known as to occur on the northeastern coast of the USA. Corrêa et al. (2018) described the three species of Claviderma Scheltema \& Ivanov, 2000 from the same area, in comparison to other species of the same

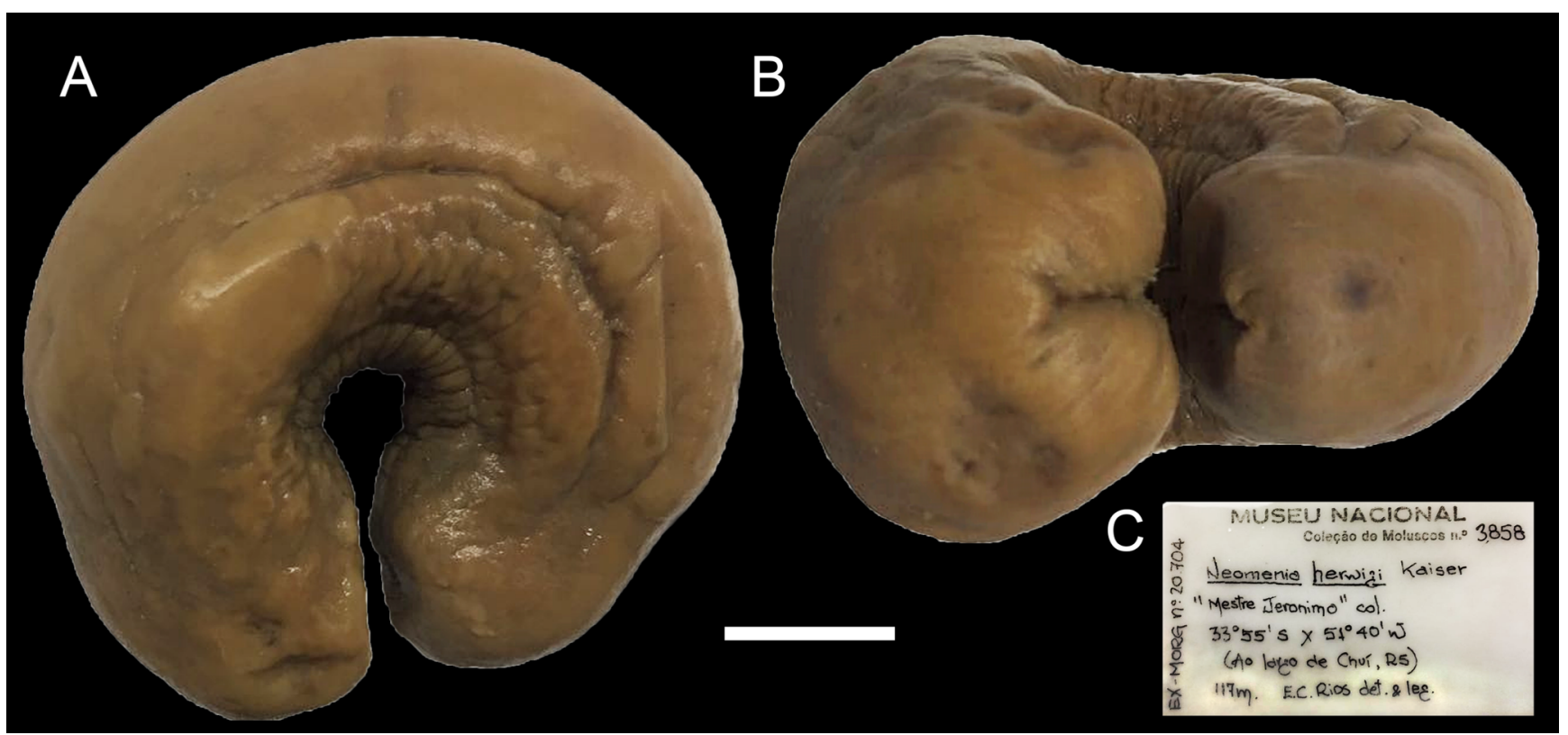

Figure 1. Neomenia herwigi. Lateral (A) and ventral (B) view of one of the two individuals used by Rios (1980) to record this species from Brazil. The label (C) shows that this specimen was originally deposited in the collection of the Museu Oceanográfico (MORG 20704); currently, it is in the molluscan collection of the National Museum of Rio de Janeiro (MNRJ 3858). Scale bar $=2 \mathrm{~cm}$. 


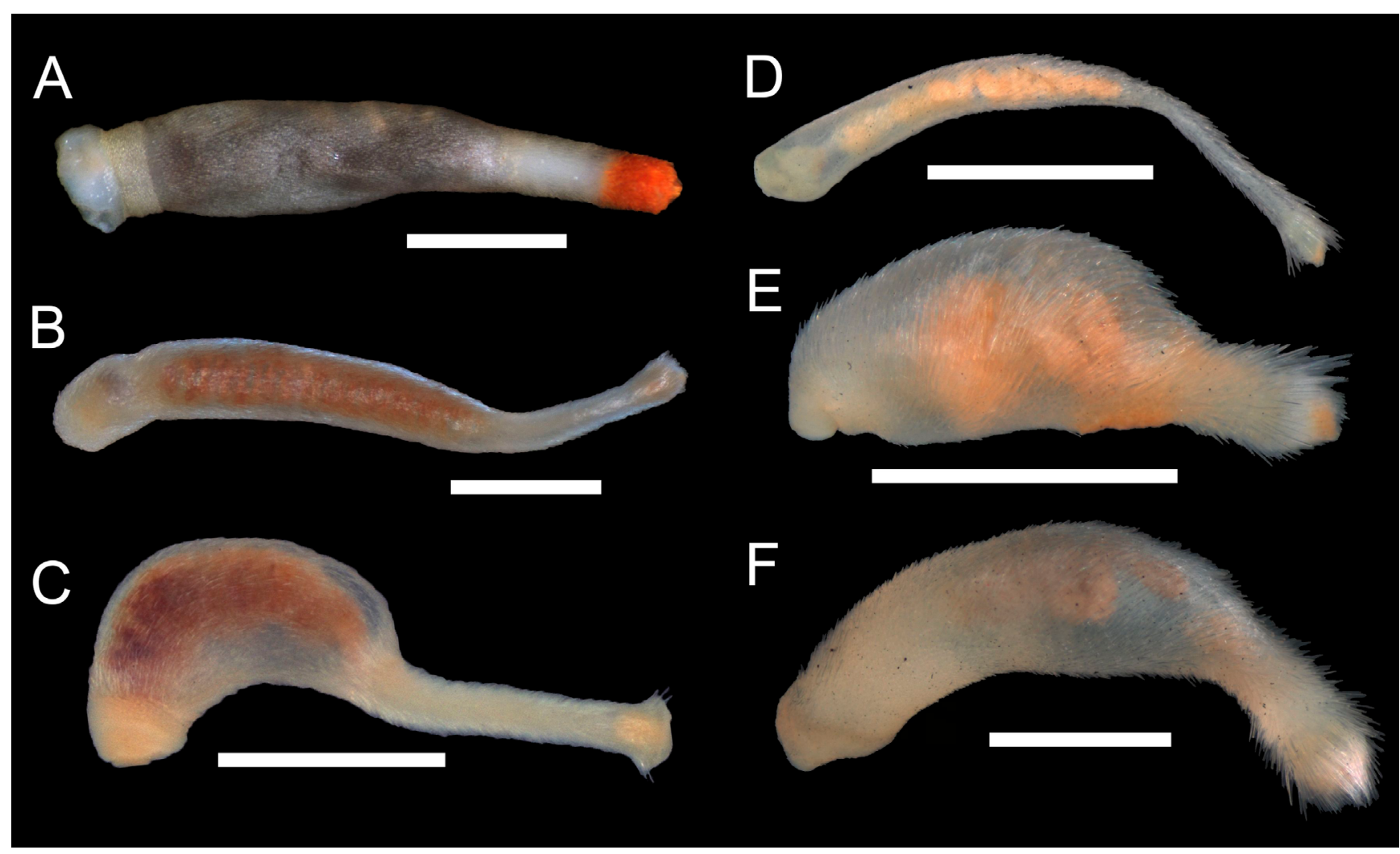

Figure 2. Caudofoveata species from Campos Basin, southeastern Brazil. A and B are F. targatus and F. acutargatus, respectively, recorded by Corrêa et al (2014); C is F. australocaudatus (Passos et al. 2017); and D-F are C. amplum, C. crassum, and C. virium, respectively (Corrêa et al. 2018). Scale bars =1 mm.

genus known from the Atlantic Ocean. Through these comparisons, they noted that species with similar body forms and with sclerites of the same shape occur off the western and eastern Atlantic coasts; these similarities could suggest that these species are sister-groups, sharing the same morphological traits as a result of common ancestry. Corrêa et al. $(2014,2018)$ and Passos et al. (2017) can be considered as the only more complete studies made on Brazilian aplacophorans, adding detailed data about the structure of the sclerites and radula, as well as about the external morphology and the bathymetric distribution of caudofoveates from Brazil. In Figure 2, all these species recorded by Corrêa et al. (2014, 2018) and Passos et al. (2017) are illustrated.

\section{Discussion}

Unlike what happens with other molluscan groups, studies on the taxonomy of Brazilian aplacophorans can be considered in their infancy. Two main problems are now pointed out as impediments for the development of more studies on these animals.

Aplacophoran species are more restricted to deep waters, a part of the marine environment less investigated in Brazil. Oceanographic studies often focus on the continental shelf, especially those interested in the research of the bottom fauna. Just a few large projects have been recently developed to study the slope and the continental rise (and even less the abyss), with most of them related to the activities of oil and gas exploitation in some specific areas. This is the case of the HABITATS and AMBES Projects, which collected a large number of samples from
Campos Basin. Indeed, there are only very few Brazilian research institutions able to investigate the marine biota from deep waters, with adequate vessels and equipment for collection of bottom samples from its large and rich coast. This situation is quite distinct from countries of the north Atlantic, where there is a long tradition of investigations of the deep sea. So, these marine organisms from Brazil are just beginning to be studied, the molluscs being one of them, including aplacophorans.

As cited before, the structure of the sclerites, radula and internal organs are essential for the description of aplacophoran species. Light microscopy is traditionally used to study them, and more recently scanning and transmission electron microscopical studies have made great discoveries (Schander et al. 2006, Ivanov \& Scheltema 2008, Ivanov et al. 2009, Kingsley et al. 2013, Kocot \& Todt 2014), as well as confocal and birefringence microscopy (Scheltema \& Ivanov 2004, Schander et al. 2006, Ivanov \& Scheltema 2007, Faller et al. 2012, Mikkelsen \& Todt 2014), and 3D reconstructions of their anatomy (Todt et al. 2008, Señaris et al. 2014, Bergmeier et al. 2016). In the Brazilian research institutions, these facilities are not always easily available and, as a consequence, aplacophoran research is limited. Up to now, studies on aplacophorans have resulted in only one $\mathrm{PhD}$ (Martins 2008) and two MSc theses (Corrêa 2016, Miranda 2016). Fortunately, there is now an increase in interests on know the deep-sea organisms in more detail, and thousands of aplacophoran specimens are waiting studies in Brazilian scientific collections. In these collections, information about the fixation methods are not always available, and so works on molecular biology (as DNA barcoding) have not been undertaken until now. 


\section{Conclusion}

Concluding, the very few records of aplacophoran species are not a true reflection of a low diversity of these animals in Brazilian waters. On the contrary, they are present and diverse in our littoral, and most likely also in deeper waters, but up to now very few of them were available for research. Thanks to large projects focusing studies on some areas (as those oil-rich ones, like Campos Basin), many samples are now arriving at the universities and museums, with new species and records awaiting to be described. Apart from these basic taxonomic studies, others on ecology, phylogeny, biogeography, and many other themes will surely be developed with the study of these molluscs. How many aplacophoran species are there in Brazil and what is the ecological importance of them in the bottom ecosystem? As the continental shelf of the Brazilian northeast is narrower and shallower, is there some breakup of the aplacophoran diversity in that area? And what is the relationship of our aplacophoran fauna with those from the north Atlantic, the Caribbean, Argentina, or Antarctica? These are some of the most basic questions to be answered by the study of these interesting animals from Brazil, a huge country from where part of its biodiversity is still little known.

\section{Acknowledgements}

This work received received financial support from $\mathrm{CNPq}$ 563106/2010-7 (Sisbiota Project), FAPESP 2010/52324-6 and CAPES. We also acknowledge FAPESP for the financial support to the senior author (Proc. 2011/50297-4), and to FAPESP and CAPES for the scholarships received by P.V.F.C. (Proc. 2011/07629-6) and M.S.M. (Proc. 2017/01081-5). Special thanks are to CENPES/Petrobras, who coordinated the HABITATS and AMBES Projects, furnishing biological material to the studies of aplacophorans in UNICAMP. Drs. A. D. Pimenta and L. R. L. Simone are acknowledged for their help while accessing the molluscan collections of the MNRJ and MZUSP, respectively. Two anonymous reviewers improved the final version of this manuscript and are also fully acknowledged for their work.

\section{Authors contributions}

Flávio Dias Passos: Designed this work and prepared the text.

Marcel Sabino Miranda: Collected the data from the bibliography and made a critical review of the final version of the manuscript. Took the pictures of $N$. herwigi.

Paulo Vinicius Ferraz Corrêa: Collected the data from the bibliography and made a critical review of the final version of the manuscript.

\section{Conflicts of interest}

The authors declare that they have no conflict of interest related to the publication of this manuscript.

\section{References}

BERGMEIER, F.S., HASZPRUNAR, G., TODT, C. \& JÖRGER, K.M. 2016 Lost in a taxonomic Bermuda Triangle: comparative 3D-microanatomy of cryptic mesopsammic Solenogastres (Mollusca). Org. Divers. Evol. 16:613-639.
BOUCHET, P., BARY, S., HÉROS, V. \& MARANI, G. 2016. How many species of molluscs are there in the world's oceans, and who is going to describe them? Trop. Deep-Sea Benthos 29:9-24.

CORRÊA, P.V.F. 2016. Prochaetodermatidae (Aplacophora, Mollusca) do sudeste do Brasil. Dissertação de mestrado, Universidade Estadual de Campinas, Campinas.

CORRÊA, P.V.F., FASSINA, P.V. \& PASSOS, F.D. 2014. Falcidens targatus and F. acutargatus: two species of Caudofoveata (Mollusca, Aplacophora) new for Brazil. J. Nat. Hist. 48:2947-2963.

CORRÊA, P. V. F.; MIRANDA, M. S. \& PASSOS, F. D. 2018. South AmericaAfrica missing links revealed by the taxonomy of deep-sea molluscs: Examples from prochaetodermatid aplacophorans. Deep-Sea Res. Pt I 132:16-28.

CRUZ, R., LINS, U. \& FARINA, M. 1998. Minerals of the radular apparatus of Falcidens sp. (Caudofoveata) and the evolutionary implications for the Phyllum Mollusca. Biol. Bull. 194:224-230.

FALLER, S., ROTHE, B.H., TODT, C., SCHMIDT-RHAESA, A. \& LOESEL, R. 2012. Comparative neuroanatomy of Caudofoveata, Solenogastres, Polyplacophora, and Scaphopoda (Mollusca) and its phylogenetic implications. Zoomorphology 131:149-170.

FORCELLI, D.O. 2000. Moluscos Magallanicos: Guia de moluscos de Patagonia y Sur de Chile. Vasquez Mazzini Editores, Buenos Aires.

GARCÍA-ÁLVAREZ, O. \& SALVINI-PLAWEN L.v. 2007. Species and diagnosis of the families and genera of Solenogastres (Mollusca). Iberus 25:73-143.

GARCÍA-ALVAREZ, O., SALVINI-PLAWEN, L.v. \& URGORRI, V. 2014. Solenogastres. In Fauna Ibérica, Vol. 38 - Mollusca, Solenogastres, Caudofoveata, Monoplacophora (G. GARCÍA-ALVAREZ, L.v. SALVINIPLAWEN, V. URGORRI \& J.S. TRONCOSO, eds.). Museo Nacional de Ciencias Naturales, Madrid, p.31-163.

GRACIA, C.A., FONTALVO, E. \& GÁMEZ, L.C. 2013. La classe Caudofoveata (Mollusca) en Mar Caribe colombiano. Bol. Invest. Mar. Cost. 42:421-424.

HASZPRUNAR, G. 2000. Is the Aplacophora monophyletic? A cladistic point of view. Am. Malac. Bull. 15:115-130.

IVANOV, D.L. 1981. Caudofoveatus tetradens gen. et sp. n. and diagnosis of the subclass Caudofoveata (Mollusca: Aplacophora). Zool. Zh. 60:18-28.

IVANOV, D.L. 1996. Chevroderma hadalis, a new species of Prochaetodermatidae (Caudofoveata, Aplacophora) from the north-west pacific. Ruthenica 6:8384.

IVANOV, D. L., MIKKELSEN, N.T. \& SCHANDER, C. 2009. Falcidens sagittiferus Salvini-Plawen, 1968: additional data on morphology and distribution (Mollusca, Aplacophora, Caudofoveata). Fauna Norv. 29:3-9.

IVANOV, D.L. \& SCHELTEMA, A.H. 2007. Chaetoderma felderi - a new giant caudofoveate species from the Gulf of Mexico (Mollusca, Aplacophora). Ruthenica 17:7-12.

IVANOV, D.L. \& SCHELTEMA, A.H. 2008. Western Atlantic Prochaetodermatidae from $35^{\circ} \mathrm{N}$ South to the Argentine Basin Including the Gulf of Mexico (Mollusca: Aplacophora). Zootaxa 1885:1-60.

IVANOV, D.L \& SCHELTEMA, A.H. 2009. 31. Aplacophora (Mollusca) of the Gulf of Mexico. In Gulf of Mexico origin, waters, and biota. Volume 1. Biodiversity (D.L. Felder, D.K. Camp, eds.). Texas A\&M University Press, Corpus Christi, p.565-567.

KAISER, P. 1976. Neomenia herwigi sp. n., ein bemerkenswerter Vertreter der Solenogastren (Mollusca, Aculifera) aus argentinischen Schelfgewässern. Mitt. Hamburg. Zool. Mus. Inst. 73:57-62.

KINGSLEY, R. J., FROELICH, J., MARKS, C.R., SPICER, L.M. \& TODT, C. 2013. Fomation and morphology of epidermal sclerites from a deepsea hydrotermal vent Solenogaster (Helicoradomenia sp., Solenogastres, Mollusca). Zoomorphology 132:1-9.

KOCOT, K. M. 2013. Recent advances and unanswered questions in deep molluscan phylogenetics. Am. Malac. Bull. 31:195-208.

KOCOT, K.M., CANNON, J.T., TODT, C., CITARELLA, M.R., KOHN, A.B., MEYER, A., SANTOS, S.R., SCHANDER, C., MOROZ, L.L., LIEB, B. \& HALANYCH, K.M. 2011. Phylogenomics reveals deep molluscan relationships. Nature 477:452-457. 
KOCOT, K.M. \& TODT, C. 2014. Three new meiofaunal solenogaster species (Mollusca, Aplacophora) from north-east pacific. J. Nat. Hist. 48:3007-3031.

MARTINS, I.X. 2008. Análise cladística dos Caudofoveata (Mollusca) e taxonomia das espécies brasileiras. Tese de doutorado, Universidade Federal da Paraíba, João Pessoa.

MIKKELSEN, N.T. \& TODT, C. 2014. Diversity of Caudofoveata (Mollusca) around Iceland and description of Psilodens balduri sp. n. Pol. Polar Res. 35:279-290.

MIRANDA, M.S. 2016. Chaetodermatidae e Limifossoridae (Mollusca, Aplacophora, Caudofoveata) da costa sudeste do Brasil. Dissertação de mestrado, Universidade Estadual de Campinas, Campinas.

MOLLUSCABASE. 2018. Chaetodermatida. Accessed through: World Register of Marine Species at: http://www.marinespecies.org/aphia. php? $\mathrm{p}=$ taxdetails \&id $=2088$ on 2018-06-04

PASSAMANECK, Y.J., SCHANDER, C. \& HALANYCH, K.M. 2004. Investigation of molluscan phylogeny using large-subunit and small-subunit nuclear rRNA sequences. Mol. Phylogenet. Evol. 32:25-38.

PASSOS, F.D., CORREAA, P.V.F. \& TODT, C. 2017. A new species of Falcidens (Mollusca, Aplacophora, Caudofoveata) from the Brazilian Southeastern coast: morphology, distribution and comparison with Falcidens caudatus (Heath, 1918) from the USA. Mar. Biodivers. DOI 10.1007/s12526-0160559-1

RIOS, E.C. 1980. An aplacophoran mollusk in Brazilian waters. Bull. Am. Malac. Union. 1980:76.

RIOS, E.C. 1985. Seashells of Brazil. Rio Grande, Fundação Universidade do Rio Grande.

RIOS, E.C. 1994. Seashells of Brazil. Rio Grande, Fundação Universidade do Rio Grande.

RIOS, E.C. 2009. Compendium of Brazilian Sea Shells. Evangraf, Rio Grande.

SALVINI-PLAWEN, L.v. 1967 Neue scandinavische Aplacophora (Mollusca, Aculifera). Sarsia 27:1-63.

SALVINI-PLAWEN, L.v. 1968. Über Lebendbeobachtungen an Caudofoveata (Mollusca, Aculifera), nebst Bemerkungen zum System der Klasse. Sarsia 31:105-126

SALVINI-PLAWEN, L.v. 1972. Die Caudofoveata des Mittelmeeres und das genus Scutopus (Mollusca, Aculifera). In Fifth European Marine Biology Symposium 1970 (B. Battaglía, ed.). Piccin Editore, Venice, p.27-51.

SALVINI-PLAWEN, L.v. 1980. A reconsideration of systematics in the Mollusca (phylogeny and higher classification). Malacologia 19:249-278.

SALVINI-PLAWEN, L.v. 1992. On Certain Caudofoveata from the VEMAExpedition. In Proceedings of the 9th International Malacological Congress (Edinburgh 1986) (E. Gittenberger \& J. Goud, eds.). Unitas Malacologica, Leiden, p.317-333.

SALVINI-PLAWEN, L.v. 1996. Falcidens vasconiensis spec. nov. (Mollusca, Caudofoveata) du plateau continental du golfe de Gascogne. Bull. Soc. Zool. Fr. 121:339-345.

SALVINI-PLAWEN, L.v. \& GARCÍA-ALVAREZ, O. 2014. Caudofoveata In Fauna Ibérica, Vol. 38 - Mollusca, Solenogastres, Caudofoveata, Monoplacophora (G. GARCÍA-ALVAREZ, L.v. SALVINI-PLAWEN, V. URGORRI \& J.S. TRONCOSO, eds.). Museo Nacional de Ciencias Naturales, Madrid, p.163-220.
SCARABINO, F. 2003. Lista sistemática de los Aplacophora, Polyplacophora y Scaphopoda de Uruguay. Comun. Soc. Malac. Urug. 8:191-96.

SCHANDER, C., SCHELTEMA, A.H. \& IVANOV, D.L. 2006. Falcidens halanychi, a new species of Chaetodermomorpha (=Caudofoveata) (Mollusca) from the northwest atlantic ocean. Mar. Biol. Res. 2:303-315.

SALVINI-PLAWEN, L.v. \& STEINER, G. 1996. Synapomorphies and plesiomorphies in higher classification of Mollusca. In Origin and Evolutionary Radiation of the Mollusca. (J.D. TAYLOR, ed.) Oxford University Press, Oxford, p.29-51.

SCHELTEMA, A.H. 1978. Position of the class Aplacophora in the phylum Mollusca. Malacologia 17:99-109.

SCHELTEMA, A.H. 1985. The aplacophoran family Prochaetodermatidae in the North American Basin, including Chevroderma n.g. and Spathoderma n.g. (Mollusca; Chaetodermomorpha). Biol. Bull. 169:484-529.

SCHELTEMA, A.H. 1990. Aplacophora as a Tethyan slope taxon: evidence from the Pacific. Bull. of Mar. Sci. 47:50-61.

SCHELTEMA, A.H. \& IVANOV, D.L. 2000. Prochaetodermatidae of the Eastern Atlantic Ocean and Mediterranean Sea (Mollusca: Aplacophora). J. Mollus. Stu. 66:313-362.

SCHELTEMA, A.H. \& IVANOV, D.L. 2004. Use of birefringence of characterize Aplacophora sclerites. Veliger 47:153-156.

SCHELTEMA, A.H., TSCHERKASSKY, M. \& KUZIRIAN, A.M. 1994. Aplacophora. In Microscopic Anatomy of Invertebrates. Mollusca I. (F.H. Harrison \& A.J. Kohn, eds.). Wiley-Liss, New York, p.13-54.

SEÑARIS, M.P., GARCÍA-ALVAREZ, O. \& URGORRI, V. 2014. Morphology of Falcidens vasconiensis (Mollusca, Caudofoveata, Chaetodermatidae), including a 3D reconstruction of the internal anatomy. J. Nat. Hist. 48:28712884

SIMONE, L.R.L. 2004. Classes Cephalopoda, Polyplacophora e Solenogastres. In Biodiversidade Bentônica da Região Sudeste-Sul do Brasil - Plataforma externa e talude. (A.C.Z. Amaral \& C.L.B. Rossi-Wongtschowski eds.) Série Documentos Revizee - Score Sul. 113.

SMITH, S.A., WILSON, N.G., GOETZ, F.E., FEEHERY, C., ANDRADE, S.C.S., ROUSE, G.W., GIRIBET, G. \& DUNN, C.W. 2011. Resolving the evolutionary relationships of molluscs with phylogenomic tools. Nature 480:364-367.

TODT, C. 2013. Aplacophoran mollusks - still obscure and difficult? Am. Malac. Bull. 31:181-187.

TODT, C., BÜCHINGER T., \& WANNINGER A. 2008. The nervous system of the basal mollusk Wirenia argentea (Solenogastres): A atudy employing immunocytochemical and 3D reconstruction techniques. Mar. Biol. Res. 4(4): 290-303

VINTHER, J., SPERLING, E.A., BRIGGS, D.E.G. \& PETERSON, K.J. 2012. A molecular palaeobiological hypothesis for the origin of aplacophoran molluscs and their derivation from chiton-like ancestors. Proc. R. Soc. B 279:1259-1268.
Received: 23/03/2018

Revised: 04/06/2018

Accepted: 12/09/2018

Published online: 11/10/2018 